\title{
Determinan saldo kas akhir tahun pada pemerintah daerah di Aceh
}

\author{
Syukriy Abdullah ${ }^{1}$, Neza Muthia ${ }^{2}$ \\ 1,2Program Studi Akuntansi, Universitas Syiah Kuala, Banda Aceh, Indonesia \\ e-mail: ${ }^{1}$ syukriyabdullah@unsyiah.ac.id
}

A R T I K E L I N F O

Article history:

Available online

Keywords:

Local government size, rebudgeting, cash balance, budget absorption, agency problems, cashless policy

\section{A B S T R A C T}

This research examines the effect of the government size, rebudgeting, previous year cash balance, and budget absorption on end-year cash balance of local governments in Aceh for 2013-2015 periods. Secondary data were extracted from local government's budget documents and financial statements by using 23 regencies and cities as samples. This research used multiple linear regression to test the hypothesis and found that the end-year cash balance is (1) positively affected by government size and previous year cash balances; (2) not affected by rebudgeting, and (3) negatively affected by budget absorption.

\begin{abstract}
A B S T R A K
Penelitian ini menguji pengaruh ukuran pemerintah daerah, perubahan anggaran, saldo kas tahun lalu, dan serapan anggaran terhadap saldo kas akhir tahun dengan sampel pemerintah daerah kabupaten dan kota di Aceh untuk tahun 2013-2015. Data yang digunakan berupa data sekunder yang diperoleh dari laporan keuangan dan dokumen anggaran dan dianalisis dengan menggunakan model regresi linier berganda. Hasil analisis menunjukkan bahwa ukuran pemerintah daerah dan saldo kas tahun lalu berpengaruh positif terhadap saldo kas akhir tahun, sedangkan serapan anggaran berpengaruh negatif dan perubahan anggaran tidak berpengaruh.
\end{abstract}

\section{Pendahuluan}

Kas merupakan aset paling penting bagi pemerintah daerah (Pemda) dalam menjalankan operasional dan penyelenggaraan fungsi pelayanan publiknya. Kas di tangan (cash holdings) merupakan uang tunai yang siap untuk dibelanjakan ${ }^{1}$ atau menjaga likuiditas (kemampuan membayar kewajiban jangka pendek) dan merupakan indikator dalam menilai kinerja anggaran pemerintah daerah. Biasanya, pemerintah daerah mencadangkan sekitar 5-9\% kas yang bersumber dari anggaran untuk berjaga-jaga (Marlowe 2011). Di sisi lain, pengelolaan kas yang tidak terpakai (idlecash) merupakan hal penting dalam pembuatan kebijakan pendapatan (Modlin dan Stewart 2012), namun pembayaran untuk belanja dihabiskan pada akhir tahun (Douglas dan Franklin 2006).

Penganggaran pemerintah daerah yang menerapkan basis kas (cash basis) menggunakan jumlah arus kas masuk sebagai ukuran kinerja penerimaan atau pendapatan dan arus kas keluar untuk mengukur kinerja pengeluaran atau belanja. Konsekuensi dari penggunaan basis kas dalam penganggaran adalah keharusan untuk menggunakan basis kas dalam pertanggungjawaban atas pelaksanaan anggaran berupa laporan keuangan, yang disebut laporan realisasi anggaran (LRA). Pada baris terbawah LRA tercantum nilai sisa lebih pembiayaan anggaran (SILPA), yang menggambarkan jumlah kas pada akhir tahun anggaran yang bersumber dari pendapatan, belanja dan pembiayaan.

Nilai kas akhir tahun pemerintah daerah disajikan dalam laporan keuangan, yakni dalam laporan posisi keuangan atau neraca. Sumber dan peruntukan kas dirinci lebih jauh dalam laporan arus kas, sampai diperoleh angka berupa saldo kas pada akhir periode akuntansi. ${ }^{2}$ Saldo kas akhir tahun pemerintah daerah menunjukkan total uang tunai dan saldo simpanan di bank yang dapat digunakan selama tahun berjalan untuk membiayai kegiatan atau memenuhi kewajiban pemerintah daerah. ${ }^{3}$

Salah satu keputusan keuangan yang terpenting pada organisasi nirlaba adalah menetapkan seberapa banyak kas yang tersedia (Ramirez 2011). Jika terlalu sedikit maka dapat membahayakan keberlangsungan

\footnotetext{
${ }^{1}$ http://dictionary.cambridge.org/dictionary/english/cash-holdings

${ }^{2}$ Istilah neraca dan laporan posisi keuangan digunakan bergantian dalam makalah ini tanpa adaperbedaan makna di antara keduanya.

${ }^{3}$ Pernyataan Standar Akuntansi Pemerintahan (PSAP) Nomor 01
} 
operasional pemerintahan, karena tidak mampu melaksanakan fungsi-fungsinya dalam melayani publik. Apabila terlalu banyak, maka akan menimbulkan financial opportunity cost dan merugikan para pemangku kepentingan (Hansmann 1980; Fisman dan Hubbard 2003). Namun, dari perspektif tata kelola dan manajerial, penentuan saldo kas atau kas di tangan pada akhir tahun di sektor nirlaba bukan merupakan fungsi dari persoalan keagenan (Ramirez 2011).

Menurut Ramirez (2011), organisasi nirlaba yang memiliki saldo kas besar cenderung melakukan investasi lebih pada aset tetap daripada organisasi yang memegang kas sedikit. Ramirez (2011) juga menemukan bahwa alasan cash holdings pada organisasi nirlaba mirip dengan perusahaan/swasta. Organisasi nirlaba yang memiliki cash holdings tinggi dicirikan dengan ukuran yang lebih kecil, memiliki pendapatan yang lebih berisiko, dan memiliki net income lebih tinggi.

Temuan Ramirez (2011) menunjukkan bahwa motif utama memegang kas adalah untuk berjaga-jaga dan spekulatif. Investasi yang likuid seperti sekuritas publik menurunkan cash holdings, sedangkan investasi non-likuid menaikkannya. Diversifikasi pendapatan akan meningkatkan cash holdings, menunjukkan lemahnya aspek pengawasannya. Jika pengeluaran lebih banyak dilakukan untuk pelaksanaan program, sehingga hanya sedikit untuk staffing dan overhead, maka cash holdings akan cenderung lebih besar.

Gore (2009) menemukan bahwa akumulasi kas lebih besar pada pemerintah kota (municipalities) disebabkan oleh variasi pendapatan tinggi, sumber pendapatan lebih sedikit, dan pertumbuhan lebih tinggi. Pemerintah daerah yang lebih besar dan menerima lebih banyak dana perimbangan mengakumulasi kas lebih sedikit. Pemerintah daerah dengan cash holdings tinggi cenderung membelanjakan lebih besar untuk biaya administrasi, gaji pejabat daerah, dan bonus. Namun, tidak ditemukan bukti bahwa kota yang kelebihan kas akan membuat kebijakan menurunkan pajak. Pemerintah daerah yang memiliki jumlah cash holdings lebih besar cenderung memiliki masalah keagenan lebih besar pula, sehingga jumlah kas pemerintah daerah pada akhir tahun berbeda satu sama lain. Salah satu cara untuk mengurangi peluang terjadi korupsi dalam pengelolaan kas adalah dengan menerapkan transaksi non tunai (cashless policy) (Ayoola 2013).

Penelitian ini ingin mengungkapkan lebih jauh faktor-faktor yang berkaitan dengan jumlah kas pada akhir tahun. Penelitian ini dilakukan pada 23 kabupaten dan kota di Aceh untuk periode anggaran 2013-2015. Objek penelitian ini diambil karena Aceh memiliki dana otsus, dana minyak dan gas (migas), Tim Anggaran Pemerintah Daerah (TAPD), partai lokal, anggaran zakat, dan dinas syari'at Islam (Wilayatul Hisbah dan Mahkamah Syar'iyah). Beberapa penyebab perbedaan ini adalah: besaran pemerintah daerah, perubahan anggaran, saldo kas tahun lalu dan serapan anggaran tahun berjalan.

\section{Tinjauan Pustaka dan Perumusan Hipotesis}

Kas hanya boleh digunakan untuk pembayaran rekening belanja yang sudah ditetapkan dalam anggaran, namun dalam praktiknya sering disalahgunakan, misalnya untuk membayar uang pelicin atau suap (grease money) (Cavico dan Mujtaba 2010). Cai et al. (2010) menyatakan bahwa perusahaan menyediakan sejumlah dana untuk memperlancar urusan bisnisnya dengan pemerintah. Chen et al. (2016) menemukan bahwa tingkat religiusitas (degree of religiosity) pada pemerintah daerah berhubungan negatif dengan tingkat hutang dan investasi, namun berhubungan positif dengan accumulated cash holdings. Menurut Chen et al. (2016), pengelolaan keuangan pada pemerintah daerah yang lebih religius akan lebih konservatif. Ayoola (2013) menyatakan bahwa transaksi tunai secara implisit mengandung risiko terjadi pungutan liar, uang pelicin dan manipulasi dokumen pertanggungjawaban (petty corruption).

Kas pada awal tahun anggaran merupakan saldo akhir kas tahun anggaran sebelumnya. Saldo kas pada akhir tahun yang dimiliki pemerintah daerah mencerminkan likuiditas pemerintah daerah sekaligus kelebihan kas yang tidak termanfaatkan selama tahun anggaran berjalan (idle money). Saldo kas yang terlalu besar mencerminkan ketidakefisienan dalam pelaksanaan aktivitas dan buruknya kualitas perencanaan kas di pemerintah daerah. Saldo kas akhir tahun di neraca akan menjadi saldo awal tahun di neraca awal pemerintah daerah, yang dapat digunakan untuk membayar kebutuhan dan kewajiban Pemda sejak awal tahun setelah penetapan anggaran tahun berkenaan. Saldo kas pada akhir tahun pada pemerintah daerah merupakan dana segar yang dapat digunakan pada awal tahun berikutnya, khususnya untuk tujuan operasional. Besaran saldo kas awal tahun berjalan sama dengan saldo di akhir tahun sebelumnya, namun dengan makna yang berbeda (Abdullah 2013a). Jumlah kas yang optimal akan memberikan benefit maksimal bagi pemerintah daerah (Ramirez 2011).

Saldo kas akhir tahun sangat dipengaruhi oleh realisasi atau serapan anggaran selama tahun berjalan. Abdullah dan Nazry (2015) menyatakan bahwa penganggaran di pemerintah daerah menganut konsep surplus dan defisit, dimana jumlah pendapatan tidak selalu sama dengan jumlah belanja. Anggaran surplus terjadi jika anggaran pendapatan lebih besar daripada anggaran belanja, dan defisit jika sebaliknya. Apabila terjadi anggaran surplus maka kelebihan dana (kas) akan dialokasikan untuk pemenuhan kewajiban atau dibuat kebijakan dalam 
pengeluaran pembiayaan, seperti untuk pembayaran pokok pinjaman dan penyertaan modal (investasi) pemerintah daerah. Sementara, jika terjadi defisit, maka harus dicari sumber uang masuk dari penerimaan pembiayaan, seperti dengan memanfaatkan sisa lebih anggaran tahun sebelumnya, melakukan pinjaman, atau dengan cara menjual kekayaan daerah yang dipisahkan (investasi) (Abdullah 2013b).

Pemerintah daerah dengan arus kas yang tidak pasti akan memegang kas dengan jumlah yang besar (Ramirez 2011). Jika dilihat dari aspek manajerial, jumlah kas yang siap digunakan (cash holdings) haruslah optimal, yakni tidak memiliki opportunity costs besar dan mendukung operasional organisasi. Pada perusahaan, manajemen kas didasarkan pada prinsip bahwa cash holdings harus dapat memaksimumkan kesejahteraan pemegang saham (Opler et al. 1999), meskipun pada kenyataannya masalah keagenan selalu muncul (Gore 2009).

\section{Pengembangan Hipotesis}

Ukuran atau besaran pemerintah (government size) merupakan faktor penting dalam pembuatan kebijakan publik (Mayer dan Greenberg 2001; Nelson dan Nollenberger 2011). Besar atau kecilnya ukuran pemerintah daerah (Pemda) menggambarkan jumlah aset yang dimilikinya dan dana yang diberikan oleh pemerintah pusat (Ilna 2015) atau cerminan dari beban pelayan publik yang dapat dilihat dari jumlah penduduk (Baber et al. 2013).

Pemerintah daerah yang lebih besar akan memiliki tekanan dari publik lebih besar dibandingkan pemerintah daerah yang lebih kecil. Oleh karena lingkup kewenangan lebih luas dan kompleksitas pelayanan publik lebih rumit pada Pemda yang lebih besar, maka ragam program dan kegiatan yang diselenggarakan akan lebih banyak, sehingga alokasi anggaran belanja juga semakin besar. Semakin besar anggaran, maka varian anggaran juga akan semakin besar (Mayper et al. 1991). Di sisi lain, lembaga perwakilan (parlemen) memiliki kecenderungan untuk memperbesar anggaran karena berkepentingan dengan outcome yang ingin dicapai dari anggaran, terutama untuk balas budi kepada pemilihnya (Gilligan dan Matsusaka 2001).

Pada praktiknya, semakin besar suatu Pemda maka semakin banyak program yang dilaksanakan sehingga semakin besar jumlah anggaran yang dikelolanya. Artinya, semakin besar suatu Pemda, maka jumlah proyek (kegiatan) yang dilaksanakan juga semakin banyak. Setiap kegiatan memiliki kecenderungan untuk tidak terserap anggaran seratus persen karena adanya perilaku oportunisma atau menggelembungkan anggaran belanja pada satuan kerja pemerintah daerah (McGuire 1981).

Saldo kas Pemda pada akhir tahun merupakan akumulasi dari saldo kas akhir tahun semua SKPD di Pemda tersebut (Abdullah dan Asmara 2007). Adanya sisa anggaran pada setiap kegiatan yang telah dilaksanakan oleh SKPD menyebabkan saldo kas pada akhir tahun semakin besar ketika jumlah kegiatan semakin banyak. Suatu kegiatan semestinya akan dilaksanakan ketika kepastian tentang cash inflow telah ada untuk merealisasikan cash outflow pada kegiatan tersebut, sehingga setiap kegiatan yang telah dilaksanakan lebih efisien atau anggarannya digelembungkan terlalu besar akan menyisakan anggaran berupa cash-in yang tidak menjadi cash-out pada tahun yang sama. Artinya, pada pemerintah daerah yang ukurannya lebih besar akan terjadi kecenderungan untuk memiliki saldo kas akhir tahun yang juga lebih besar. Dengan demikian, hipotesis yang dapat diajukan adalah: $\mathrm{H}_{1}$ : Ukuran pemerintah daerah berpengaruh positif terhadap saldo kas akhir tahun.

Biasanya perubahan dilakukan untuk perbaikan capaian kinerja (Ruhmaini et al. 2018). Adanya perubahan anggaran akan menyebabkan estimasi dana yang diterima dan dikeluarkan pemerintah juga akan berubah, seiring dengan adanya penyesuaian kebutuhan daerah dengan kemampuan keuangan daerah (Forrester 1991). Perubahan sumber dan peruntukan dana ini diperkirakan dapat mempengaruhi saldo kas pemerintah daerah pada akhir periode anggaran.

Perubahan anggaran pada pemerintah daerah dapat terjadi karena beberapa alasan, diantaranya ekonomi, politik, dan sosial, meskipun umumnya disebabkan oleh faktor finansial dan kebutuhan fiskal (Forrester dan Mullins 1992; Anessi-Pessina et al. 2012). Bias dalam penganggaran awal (Jones dan Euske 1991) dan misrepresentasi dalam penyajian angka anggaran (Larkey dan Smith 1989) secara tidak langsung memiliki kaitan dengan perubahan anggaran. Kecenderungan agency atau unit kerja pada pemerintahan sebagai budget maximizer (McGuire 1981) dan perilaku oportunis para pembuat keputusan (Smith dan Bertozzi 1998; Abdullah 2012) menyebabkan penyesuaian anggaran dalam tahun berjalan menjadi sebuah keniscayaan. Perubahan anggaran terjadi pada hampir semua unit kerja pemerintah daerah/SKPD (Abdullah dan Nazry 2015; Alasa 2016; Triana 2016).

Perubahan anggaran juga mempengaruhi besaran surplus/defisit anggaran selama tahun berjalan karena berkenaan dengan revisi atas anggaran penerimaan dan pengeluaran (Abdullah dan Junita 2016), sehingga dapat terjadi pada semua komponen Anggaran Pendapatan Belanja Daerah (APBD), yakni pendapatan, belanja dan pembiayaan (Abdullah 2013c). Beberapa studi terdahulu memberi bukti empiris bahwa perubahan anggaran terjadi pada anggaran belanja barang dan jasa (Marzalita et al. 2014), belanja modal (Martunis et al. 2014), dan belanja langsung (Nikmawati et al. 2016). 
Perubahan anggaran/APBD dapat diartikan sebagai upaya pemerintah daerah untuk menyesuaikan rencana keuangannya dengan perkembangan situasi dan kondisi yang terjadi, serta untuk mengurangi varian anggaran atau menaikkan serapan anggaran pada akhir tahun. Oleh karena anggaran daerah menganut basis kas, maka perubahan anggaran akan memperkecil saldo kas pada akhir tahun (Abdullah dan Nazry 2015). Oleh karena suatu pemerintahan terdiri dari banyak satuan kerja atau SKPD, maka pada hakikatnya perubahan anggarannya merupakan gabungan dari revisi anggaran pada semua SKPD (Alasa 2016; Kusyanti et al. 2014; Triana 2016).

Dari perspektif keagenan, dimana agent akan berperilaku self-interest dalam pengambilan keputusan anggaran (Halim dan Abdullah 2006), perubahan anggaran cenderung digunakan untuk mencapai tujuannya (Abdullah dan Nazry 2015; Abdullah dan Rona 2014). Perubahan anggaran belanja dapat berupa penambahan alokasi untuk kegiatan tertentu yang tidak dapat diselesaikan oleh pemerintah daerah sampai akhir tahun anggaran. Akibatnya, akan terjadi sisa anggaran sebesar jumlah anggaran yang belum dibayarkan yang menjadi tambahan saldo kas pada akhir tahun. Hipotesis kedua dapat dinyatakan seperti berikut:

$\mathrm{H}_{2}$ : Perubahan anggaran berpengaruh terhadap saldo kas akhir tahun.

Abdullah (2013c) menyatakan bahwa SiLPA merupakan bentuk lain dari SILPA, tetapi berbeda tahun anggaran dan maknanya. Nilai riil SILPA muncul di laporan realisasi anggaran (LRA), sedangkan nilai SiLPA muncul di dalam APBD pada awal tahun. Beberapa pemerintah daerah membuat anggaran SILPA nihil atau bernilai nol atau diprediksi tidak ada sisa anggaran pada akhir tahun setelah APBD dilaksanakan. Nilai anggaran SILPA sama dengan nol jika nilai anggaran Pembiayaan Neto sama dengan nilai anggaran Surplus/Defisit. Rencana nilai SILPA sama dengan nol pada kenyataannya mustahil terjadi karena pada akhir tahun anggaran selalu ada sisa anggaran. Bias dalam penganggaran merupakan penyebab mengapa estimasi anggaran tidak selalu akurat (Jones dan Euske 1991; Mayper et al. 1991).

Menurut Abdullah (2013c), penganggaran di eksekutif mengandung budget slack, yakni selisih antara potensi/kebutuhan dengan target anggaran, baik berupa target yang terlalu rendah atau mark-down (untuk pendapatan asli daerah/PAD) maupun target yang terlalu tinggi atau mark-up (untuk belanja). Implikasi kedua bentuk self-interest penyusun anggaran ini adalah terjadinya varian anggaran, yang nilainya baru data dipastikan pada akhir tahunanggaran setelah selesai diaudit oleh BPK RI (Badan Pemeriksa Keuangan Republik Indonesia).

Pemda memiliki kecenderungan untuk menggunakan target kinerja tahun lalu sebagai patokan untuk menentukan target kinerja pada tahun berkenaan, terutama dalam kondisi terdapat asimetri informasi (Abdullah dan Junita 2016). Saldo kas tahun lalu berupa SiLPA akan digunakan pada tahun anggaran berjalan dalam dua bentuk, yakni: (1) untuk melanjutkan kegiatan yang belum selesai dikerjakan pada tahun sebelumnya, dan (2) membiayai kegiatan baru yang tidak teranggarkan sumber pendanaannya dalam anggaran berjalan. Oleh karena itu, apabila saldo kas tahun lalu dianggap baik (favorable), maka Pemda memiliki kecenderungan akan menentukan saldo kas tahun berkenaan mirip dengan saldo kas pada tahun sebelumnya (budget ratcheting). Menurut Marlowe (2011), dalam keuangan publik hampir selalu terjadi simple heuristic, yakni pengambilan keputusan yang didasarkan pada apa yang sudah biasa dialami/dilakukan. Berdasarkan pemahaman ini, maka hipotesis ketiga adalah:

$\mathrm{H}_{3}$ : Saldo kas tahun lalu berpengaruh positif terhadap saldo kas akhir tahun.

Pada beberapa kasus terjadi fenomena budget ratcheting, dimana anggaran atau target tahun berkenaan mencontoh anggaran atau realisasi tahun sebelumnya (Abdullah dan Junita 2016; Lim 2011). Realisasi pendapatan dan realisasi belanja akan menyebabkan terjadinya aliran kas masuk dan keluar. Oleh karena itu, saldo kas tahun lalu diperkirakan dapat mempengaruhi saldo kas tahun berikutnya.

Anggaran pemerintah daerah merupakan pernyataan mengenai estimasi kinerja yang hendak dicapai selama periode waktu tertentu yang dinyatakan dalam ukuran finansial (Mardiasmo 2009). Setelah dilaksanakan, capaian atas target-target anggaran dipertanggungjawabkan dalam bentuk laporan pertanggungjawaban atas pelaksanaan anggaran dan laporan keuangan pemerintah daerah. Oleh karena konsep penganggaran di Indonesia menggunakan basis kas, maka capaiannya berupa realisasi atau serapan anggaran juga mencerminkan nilai kas yang telah diterima dan dikeluarkan, dan selisih di antara keduanya selama satu periode anggaran, yang disebut surplus atau defisit anggaran. Surplus atau defisit anggaran identik dengan besaran saldo kas yang bersumber dari operasi normal pemerintah daerah pada akhir tahun.

Andalia et al. (2012) dan Abdullah dan Nazry (2015) memberikan bukti empiris tentang serapan anggaran. Serapan anggaran adalah capaian dalam merealisasikan anggaran belanja pada suatu pemerintah daerah. Menurut Abdullah dan Nazry (2015), serapan anggaran tahun berjalan menggambarkan jumlah dana atau uang pemerintah daerah yang telah dibayarkan selama tahun berjalan dalam bentuk belanja daerah. Anggaran yang terserap atau 
terealisasi tidak selalu (tidak harus) mencapai seratus persen atau sama dengan jumlah yang dianggarkan, sehingga selalu timbul spending variances, yakni selisih antara anggaran dan realisasi belanja (Mayper et al. 1991).

Serapan anggaran mencerminkan anggaran belanja yang terealisasi dalam satu periode anggaran. Besaran serapan anggaran berbanding terbalik dengan saldo kas, terutama yang berasal dari sisa anggaran. Artinya, bila suatu anggaran belanja terealisasi (terserap), maka kas akan terpakai (cash-out). Dari perspektif kinerja (realisasi atas anggaran belanja) pemerintah daerah secara keseluruhan, serapan anggaran yang tinggi atau sisa kas yang kecil adalah hal bagus. Realisasi belanja yang besar menunjukkan bahwa program pembangunan dan pelayanan publik telah dilakukan semaksimal mungkin sesuai dengan target yang telah ditetapkan dalam anggaran (Abdullah dan Nazry 2015). Hipotesis keempat dari penelitian ini yaitu:

$\mathrm{H}_{4}$ : Serapan anggaran tahun berjalan berpengaruh negatif terhadap saldo kas akhir tahun.

\section{Metoda Penelitian}

\section{Data dan Sampel}

Data sekunder yang digunakan dalam penelitian ini berasal dari laporan keuangan pemerintah daerah 23 (dua puluh tiga) kabupaten dan kota di Aceh tahun 2013-2015, sehingga diperoleh 69 observasi. Pemilihan sampel ini didasarkan pada kriteria berikut: (a) berstatus otonomi khusus; (b) memasukkan zakat sebagai komponen Pendapatan Asli Daerah (PAD); dan (b) memiliki data keuangan untuk tahun 2013-2015.

\section{Definisi dan Pengukuran Variabel}

Variabel dependen dalam penelitian ini adalah Saldo Kas Akhir Tahun (SKAT), yang diukur menggunakan besaran angka saldo kas dalam Neraca tahun berkenaan. Variabel independen terdiri dari (a) Ukuran Pemerintah Daerah (UP), yang diukur menggunakan besaran populasi atau jumlah penduduk; (b) Perubahan APBD (PA), yang diukur menggunakan besaran selisih antara total belanja dalam APBD setelah perubahan dan APBD murni; (c) Saldo Kas Tahun Lalu (SKTL), yang diukur menggunakan nilai Kas di Neraca pada awal tahun berkenaan; dan (d) Serapan Anggaran (SA), yang diukur menggunakan jumlah realisasi belanja tahun berjalan.

\section{Metoda Analisis Data dan Pengujian Hipotesis}

Penelitian ini menguji hipotesis dengan menggunakan model regresi linier berganda untuk memberikan bukti empiris tentang pengaruh 4 (empat) prediktor, yakni ukuran atau besaran pemerintah daerah (UP), perubahan anggaran (PA), saldo kas tahun lalu (SKTL), dan serapan anggaran tahun berjalan (SA), terhadap saldo kas akhir tahun (SKAT) pada pemerintah daerah di Aceh. Arah pengaruh masing-masing variabel ditentukan berdasarkan tanda koefisien regresi dan penentuan penolakan atas hipotesis didasarkan pada nilai signifikansi (Sig.) dengan patokan $\alpha=5 \%$.

\section{Hasil dan Pembahasan}

\section{Hasil Pengujian Hipotesis}

Hasil pengolahan data dengan menggunakan regresi linier berganda dapat dilihat pada Tabel 1.

Tabel 1. Hasil Pengujian Regresi Linier Berganda

\begin{tabular}{|c|c|c|c|c|c|}
\hline \multicolumn{6}{|c|}{$\begin{array}{l}\text { Persamaan Regresi: } \\
S K A T=26608152126+143211,800 U P+0,094 P A+0,794 \text { SKTL-0,046SATB+e }\end{array}$} \\
\hline$t$-value & 2,509 & 2,905 & 1,869 & 6,455 & -2190 \\
\hline Sig.-value & 0,015 & $0,005 *$ & 0,066 & $0,000 *$ & $0,032 *$ \\
\hline F-value/F Sig. & \multicolumn{5}{|c|}{$22,208 / 0,000$} \\
\hline$R / R^{2}$ & & $0,762 / 0$ & & & \\
\hline
\end{tabular}

Hasil pengujian untuk model regresi (uji F), untuk menjawab apakah semua variabel independen yang dimasukkan dalam model secara bersama-sama berpengaruh terhadap variabel dependen, memberikan nilai $F$ sebesar 22,208 dan signifikansi 0,000 (lebih besar dari 5\%). Hal ini bermakna bahwa variabel UP, PA, SKTL dan SA secara bersama-sama berpengaruh terhadap SKAT.

Nilai $R$ (koefisien korelasi) yang diperoleh adalah sebesar 0,762 atau $76 \%$ dan nilai $R^{2}$ (koefisien determinasi) adalah sebesar 0,581 atau $58 \%$. Hal ini menunjukkan bahwa korelasi antara semua variabel bebas 
dengan variabel terikat adalah sebesar 76\% dan variasi SKAT pada Pemda di Aceh untuk tahun 2013-2015 sebesar $58 \%$ ditentukan oleh UP, PA, SKTL, dan SA. Sebesar 0,42 atau 42\% variasi pada SKAT ditentukan oleh variabel lain yang tidak dimasukkan ke dalam model penelitian ini.

Konstanta (a) sebesar 26608152126. Artinya, jika semua variabel bebas (ukuran pemda, perubahan anggaran, saldo kas tahun lalu, dan serapan anggaran tahun berjalan) dianggap konstan, maka besarnya saldo kas akhir tahun 23 kabupaten/kota di Aceh periode 2013-2015 adalah sebesar 26608152126.

\section{Pengaruh Ukuran Pemda terhadap Saldo Kas Akhir Tahun}

Berdasarkan hasil pengujian statistik (lihat Tabel 1), diperoleh nilai signifikansi untuk pengaruh variabel Ukuran Pemda (UP) terhadap variabel Saldo Kas Akhir Tahun sebesar 0,015 atau 1,5\%, yang berada di bawah tarif signifikansi 0,05 atau $\alpha=5 \%$. Hal ini bermakna bahwa variabel UP berpengaruh terhadap Saldo Kas Akhir Tahun pada 23 kabupaten/kota di Aceh. Nilai koefisien variabel UP bertanda positif sebesar 2,905 bermakna bahwa semakin besar ukuran Pemda, maka semakin besar Saldo Kas Akhir Tahun. UP yang besar menyebabkan kas yang dipegang oleh pemerintah daerah juga lebih besar/banyak. Hasil ini sesuai dengan prediksi dalam hipotesis penelitian pertama $\left(\mathrm{H}_{1}\right)$ yang menyatakan bahwa "ukuran pemerintah daerah berpengaruh positif terhadap saldo kas akhir tahun".

Pada Pemda yang lebih besar (dalam penelitian ini diukur dengan jumlah penduduk), program dan kegiatan yang dilaksanakan lebih banyak dan beragam. Pada saat pelaksanaan kegiatan, ada kecenderungan bahwa tidak seluruh anggaran kegiatan akan terpakai atau terealisasi (budget variances), sehingga masih ada anggaran belanja yang tersisa. Penganggaran pemerintah daerah yang menggunakan basis kas (asumsi: anggaran berimbang), menempatkan sisa anggaran sebagai komponen saldo kas akhir tahun. Hasil ini konsisten dengan temuan Ramirez (2011).

Simpulan bahwa semakin besar ukuran pemerintah daerah maka semakin besar saldo kas akhir tahun memiliki beberapa isu untuk didiskusikan. Pertama, kas dapat bersumber dari pelampauan target pendapatan dan penerimaan pembiayaan atau tidak tercapainya target belanja, namun saldo pada akhir tahun akan dipengaruhi kebijakan dan tindakan pada saat pelaksanaan anggaran. Semakin besar jumlah kegiatan dan nilai anggaran suatu pemerintah daerah, maka diskresi pada saat implementasi juga semakin besar.

Kedua, sebagian dari kegiatan bersifat "multi-years", dimana pelaksanaan kegiatan melampaui waktu satu tahun anggaran, baik disengaja atau pun tidak. Jika disengaja dengan persetujuan parlemen (DPRD), maka arus kas dapat diprediksi lebih baik karena sumber pembiayaan yang lebih pasti. Namun, jika tidak disengaja atau "disengaja dengan niat busuk", maka arus kas menjadi tidak pasti, sehingga berpengaruh pada saldo kas akhir tahun. Konflik kepentingan sering terjadi dalam eksekusi kegiatan (projects) ini, termasuk dalam pengadaannya (tendering). Kegiatan tahun jamak akan mempengaruhi jumlah dan beban anggaran tahun berikutnya.

\section{Pengaruh Perubahan Anggaran terhadap Saldo Kas Akhir Tahun}

Berdasarkan hasil pengujian statistik (lihat Tabel 1), variabel perubahan anggaran tidak berpengaruh terhadap saldo kas akhir tahun, dimana nilai signifikansi variabel perubahan anggaransebesar 0,066 berada di atas $\alpha=5 \%$. Meskipun nilai koefisien variabel Perubahan Angaran positif sebesar 1,869 terhadap Saldo Kas Akhir Tahun, namun secara statistik tidak dapat disimpulkan bahwa jika semakin tinggi perubahan anggaran suatu daerah, maka akan semakin tinggi pula saldo kas akhir tahun pada daerah tersebut. Berdasarkan hasil ini dapat disimpulkan bahwa hipotesis kedua $\left(\mathrm{H}_{2}\right)$ yang menyatakan bahwa "Perubahan anggaran berpengaruh terhadap saldo kas akhir tahun" ditolak.

Perubahan anggaran merupakan alat untuk menyesuaikan target-target anggaran dengan kondisi terkini dalam pelaksanaan anggaran. Apabila kegiatan sudah selesai dilaksanakan sebelum perubahan anggaran, namun masih ada sisa anggaran untuk kegiatan tersebut, maka sisa ini dihilangkan dalam perubahan anggaran, sehingga nilai anggarannya sama dengan jumlah belanja yang terealisasi. Artinya, tidak terjadi varian anggaran, sehingga tidak menyisakan anggaran, yang pada akhirnya mempengaruhi saldo kas akhir tahun.

Forrester dan Mullins (1992) sejalan dengan Abdullah dan Nazry (2015) menyatakan bahwa penyesuaian anggaran belanja dilakukan untuk membuat perencanaan program dan kegiatan menjadi lebih efisien dan efektif. Artinya, perubahan anggaran belanja akan mendekatkan jumlah uang keluar yang direncanakan dengan jumlah yang direalisasikan, sehingga varian anggaran menjadi hilang atau semakin kecil. Suatu kegiatan akan terlihat efektif ketika serapan anggaran dapat dioptimalkan, dimana pada akhir tahun tidak banyak sisa anggaran/saldo kas akhir tahun di neraca pemerintah daerah.

Namun, dari perspektif keagenan, perubahan anggaran dapat digunakan sebagai media untuk "menitipkan" alokasi belanja tertentu yang pada akhir tahun menjadi SILPA (saldo kas) untuk digunakan (direalisasikan) pada awal tahun anggaran berikutnya dalam bentuk kegiatan lanjutan (DPAL) atau carryover 
(Douglas dan Franklin 2006; Abdullah dan Rona 2014). Oleh karena itu, sulit untuk diprediksi bahwa perubahan anggaran akan memperbesar atau memperkecil saldo kas pada akhir tahun anggaran. Anessi-Pessina et al. (2012) menyatakan bahwa proses perubahan anggaran sangat mirip dengan proses penyusunan anggaran awal (initial budget), sehingga perilaku oportunistik agent tetap dapat terjadi (Smith dan Bertozzi 1998; Abdullah dan Asmara 2007).

\section{Pengaruh Saldo Kas Tahun Lalu terhadap Saldo Kas Akhir Tahun}

Berdasarkan hasil pengujian statistik (lihat Tabel 1), secara parsial variabel Saldo Kas Tahun Lalu berpengaruh (signifikan) terhadap Saldo Kas Akhir Tahun pada kabupaten/kota di Aceh. Hal ini dapat dilihat dari nilai signifikansi sebesar 0,000 , lebih kecil dari taraf signifikansi $0,05(\alpha=5 \%)$. Tanda positif untuk koefisien variabel SKTL sebesar 6,455 terhadap saldo kas akhir tahun bermakna bahwa jika semakin tinggi saldo kas tahun lalu suatu daerah, maka semakin besar saldo kas akhir tahun pada daerah tersebut. Artinya, hipotesis ketiga $\left(\mathrm{H}_{3}\right)$ yang menyatakan bahwa "Saldo kas tahun lalu berpengaruh positif terhadap saldo kas akhir tahun" tidak dapat ditolak atau hipotesis terkonfirmasi oleh hasil penelitian ini.

Penggunaan data anggaran tahun sebelumnya sebagai dasar dalam menentukan jumlah anggaran tahun berjalan merupakan fenomena yang lazim terjadi dalam pengelolaan keuangan di pemerintahan daerah (simple heuristic). Khusus untuk penganggaran, menurut Abdullah dan Junita (2016), penggunaan pola dan besaran revisi anggaran tahun sebelumnya sebagai patokan untuk revisi anggaran tahun berjalan merupakan hal yang biasa dilakukan (budget ratcheting). Fenomena ini terjadi juga dalam menentukan besaran saldo kas pada akhir tahun, yang mengandung kewajiban untuk menyelesaikan pembayaran belanja yang belum tuntas di tahun berjalan pada tahun anggaran berikutnya dan dana pihak ketiga yang belum disetorkan oleh Pemda. Oleh karena saldo kas akhir tahun terkait dengan basis kas yang digunakan dalam penganggaran pemerintah daerah, maka perilaku dalam penganggaran juga terjadi dalam pengelolaan kas.

Saldo kas tahun lalu pada suatu SKPD seharusnya menjadi saldo awal kas tahun berjalan pada SKPD berikutnya. ${ }^{4}$ Namun, dalam konsep pengelolaan keuangan daerah, uang tunai atau kas yang ada di tangan bendahara harus disetorkan ke kas daerah. Praktik seperti ini merupakan bagian dari internal control untuk mengurangi peluang terjadinya penyalahgunaan uang daerah. Pada level pemerintah daerah, seluruh uang daerah dikelola oleh satuan kerja pengelola keuangan daerah (SKPKD) selaku bendahara umum daerah (BUD), di mana saldo kas pada akhir tahun berjalan akan menjadi saldo awal kas pada tahun berikutnya. Di sisi lain, saldo akhir tahun berjalan akan menjadi patokan untuk besaran saldo kas akhir tahun berikutnya.

Temuan ini mengindikasikan adanya kondisi "stabil" atau keinginan untuk menghindari masalah karena adanya perbedaan mencolok dengan kebiasaan yang telah terjadi selama ini pada SKPD dan Pemda. Persoalan yang muncul pada awal tahun anggaran adalah tidak tersedianya kas pada awal tahun anggaran sebagai akibat dari keterlambatan dalam penatausahaan, baik dengan atau tanpa kondisi penetapan APBD yang terlambat. Hal ini mengkonfirmasi adanya simple heuristic dalam "penentuan" saldo akhir kas (Marlowe 2011).

\section{Pengaruh Serapan Anggaran Tahun Berjalan terhadap Saldo Kas Akhir Tahun}

Pada Tabel 1, dapat dilihat bahwa serapan anggaran tahun berjalan (SA) berpengaruh (signifikan) terhadap saldo kas akhir tahun (SKAT) pada kabupaten/kota di Aceh. Hal ini dapat dilihat dari nilai signifikansi sebesar 0,032 yang berada di bawah tarif signifikansi 0,05 atau $\alpha=5 \%$. Hubungan negatif sebesar $-2,190$ bermakna bahwa jika semakin tinggi serapan anggaran tahun berjalan suatu pemerintah daerah, maka semakin rendah saldo kas akhir tahun pada daerah tersebut. Hasil ini tidak menolak hipotesis penelitian yang menyatakan bahwa "serapan anggaran tahun berjalan berpengaruh negatif terhadap saldo kas akhir tahun."

Hasil ini sesuai dengan prediksi dalam teori dan hipotesis yang menyatakan bahwa saldo kas akhir tahun sangat ditentukan oleh besaran serapan anggaran belanja dalam pelaksanaan anggaran daerah. Belanja merupakan salah satu bentuk penggunaan kas dalam penganggaran yang menggunakan basis kas. Pengunaan kas untuk membayar belanja selama tahun anggaran berjalan akan mengurangi saldo kas pada akhir tahun. Di sisi lain, adanya realisasi pendapatan dan daan pihak ketiga yang ada di Pemda yang belum disetor akan meningkatkan saldo kas pada akhir tahun.

Namun, perlu dipahami bahwa serapan anggaran belanja meliputi alokasi murni untuk tahun anggaran berjalan dan sisa atau lanjutan pekerjaan yang telah dialokasikan pada tahun sebelumnya (kegiatan lanjutan). Secara teknis, kegiatan lanjutan akan dilaksanakan terlebih dahulu pada awal tahun, sementara kegiatan murni tahun berjalan terlebih dahulu harus melalui proses administrasi dan/atau tendering. Implikasinya, kegiatan lanjutan

\footnotetext{
${ }^{4}$ Praktik ini lazim terjadi dalam organisasi bisnis karena selalu harus tersedia dana kas kecil (pettycash) untuk operasional.
} 
menjadi solusi agar mesin birokrasi bias berjalan pada awal tahun anggaran ketika kegiatan dalam APBD murni masih dalam proses pelelangan.

Serapan anggaran merupakan salah satu ukuran kinerja bagi pemerintah daerah. Semakin besar porsi anggaran yang terserap atau terealisasi, maka semakin besar pula porsi program dan kegiatan yang telah dilaksanakan, sehingga semakin besar kemungkinan tercapainya keluaran (output) dan hasil (outcome) dari pelayanan publik. Oleh karena itu, seharusnya saldo kas pada akhir tahun tidak besar, karena idle cash yang besar memiliki risiko berupa kehilangan atau masalah keagenan. Pada pemerintah daerah sendiri, unsur spekulatif nyaris tidak ada karena mekanisme penerimaan daerah dari pendapatan berupa dana alokasi umum (DAU) diberikan 1/12. Artinya, tidak perlu disiapkan kas untuk mengantisipasi kejadian luar biasa karena kebijakan untuk belanja tidak terduga sudah ditetapkan oleh kepala daerah.

Masalah keagenan dalam serapan anggaran yang rendah dapat timbul dari adanya penyesuaian anggaran yang memperburuk kinerja (varian anggaran belanja semakin besar). Menteri Dalam Negeri setiap tahun mengingatkan melalui regulasi tentang pedoman penyusunan APBD bahwa dalam perubahan APBD tidak boleh dialokasikan anggaran belanja fisik baru yang tidak dapat diselesaikan pelaksanaannya sampai akhir tahun anggaran, agar tidak terjadi sisa anggaran (anggaran tidak terserap seratus persen). Pada kenyataannya, banyak sekali program dan kegiatan mengalami penyesuaian sebagai akibat adanya bias dalam penyusunan anggaran murni (Larkey dan Smith 1989).

Fenomena yang sering muncul pada akhir tahun anggaran adalah penarikan dana besar-besaran dari rekening kas daerah di bank (rush) dan pembayaran semua sisa kewajiban yang harus diselesaikan sampai menjelang akhir tahun anggaran. Oleh karena penilaian kinerja SKPD didasarkan pada persentase realisasi anggaran, maka untuk mencapai serapan yang tinggi pada akhir tahun anggaran dilakukan pembayaranpembayaran untuk semua belanja daerah oleh SKPD. Praktik ini justru menimbulkan pemborosan dalam pelaksanaan anggaran (Douglas dan Franklin 2006). Menurut Ayoola (2013), penerapan kebijakan transaksi non tunai (cashless policy) dapat menjadi solusi untuk mengurangi penyalahgunaan anggaran (petty corruption) pada pemerintah daerah.

\section{Simpulan}

Hasil penelitian menunjukkan bahwa Ukuran Pemda dan Saldo Kas Tahun Lalu berpengaruh positif, Serapan Anggaran berpengaruh negatif, dan Perubahan Anggaran tidak berpengaruh terhadap Saldo Kas Akhir Tahun pada 23 kabupaten/kotadi Aceh untuk tahun anggaran 2013-2015. Keterbatasan penelitian ini adalah; Pertama, hanya menggunakan sampel kabupaten dan kota di Aceh, sehingga generalisasi atas hasil yang ditemukan untuk seluruh kabupaten dan kota di Indonesia tidak dapat dilakukan. Hal ini disebabkan keunikan Pemda yang menjadi sampel, yakni adanya kekhususan dalam hal keuangan berupa dana otonomi khusus dan penerapan syariat Islam. Kedua, data yang digunakan adalah data sekunder, sehingga beberapa fenomena belum dapat diungkap namun diduga dapat mempengaruhi besaran kas pada akhir tahun. Ketiga, adanya saldo kas di satuan kerja semi pemerintah daerah, yakni Baitul Mal, yang diakui sebagai kas daerah, meskipun sesungguhnya bukan dana yang dapat digunakan oleh pemda dalam operasionalnya.

Berdasarkan keterbatasan dan fenomena yang ada di pemerintahan daerah, ada beberapa saran dapat diberikan untuk penelitian berikutnya. Pertama, menambahkan beberapa variabel lainnya yang diduga mempengaruhi saldo kas akhir tahun, seperti keterlambatan penetapan anggaran daerah, tingkat kemandirian daerah, kapasitas sumberdaya manusia, dan kecenderungan petty corruption. Kedua, penelitian ini dilakukan di Aceh, yang memiliki perbedaan status otonomi yang berbeda dengan provinsi lain di Indonesia. Perbandingan dengan provinsi lain yang tidak berstatus otonomi khusus dapat dilakukan untuk mengetahui apakah ada implikasi dari status tersebut terhadap kebijakan anggaran dan pengelolaan kas pada pemerindah daerah kabupaten dan kota. Ketiga, penggunaan data sekunder belum dapat mengungkapkan seluruh faktor penting yang menentukan besaran saldo kas akhir tahun. Penggunan data primer direkomendasikan dalam studi berikutnya untuk memberikan tambahan bukti empiris untuk isu saldo kas akhir tahun ini. Keempat, adanya kewajiban pemerintah daerah untuk mulai menerapkan transaksi non tunai (cashless policy) menjadi isu baru yang harus dikaji lebih jauh, apakah memiliki akibat terhadap besaran saldo kas akhir tahun. Terakhir, kelima, perlu dilakukan pembedaan status kas akhir tahun, apakah bersumber dari sisa anggaran yang bersifat bebas atau terikat (sisa anggaran untuk kegiatan lanjutan/DPAL). Sisa anggaran kegiatan lanjutan berkaitan dengan masalah keagenan yang salah satunya bersumber dari perilaku moral hazard pengambil keputusan pada saat melakukan perubahan anggaran dalam tahun berjalan.

Implikasi untuk pembuatan kebijakan anggaran yaitu; pertama, ketika ukuran Pemda memiliki pengaruh positif terhadap saldo kas (SILPA), secara tersirat menunjukkan adanya varian belanja yang signifikan sebagai implikasi kompleksnya permasalahan di masyarakat yang harus diselesaikan oleh Pemda melalui anggaran daerah. 
Oleh karena itu, kebijakan belanja harus diperbaiki sehingga bias dan varian anggaran dapat diminimalisir. Kedua, ketika ukuran kinerja anggaran Pemda menggunakan realisasi anggaran, maka perubahan anggaran seharusnya memperbaiki kinerja dimaksud yang secara implisit mengarah pada saldo kas yang rendah pada akhir tahun/serapan anggaran tinggi. Artinya, pengaruh perubahan anggaran yang tidak signifikan terhadap saldo kas kemungkinan dikarenakan perubahan anggaran dilakukan "hanya di atas kertas" atau tidak memiliki kaitan dengan aliran kas Pemda. Untuk itu, masalah keagenan dapat dikaji lebih lanjut terhadap perubahan anggaran ini. Terakhir, pengendalian untuk pembayaran dan penarikan uang dari kas daerah oleh SKPD perlu ditingkatkan karena sebagian tidak sesuai dengan pembayaran riil, terutama pada akhir tahun anggaran (Douglas dan Franklin 2006).

\section{Daftar Referensi}

Abdullah, S. 2012. Varians anggaran pendapatan dan varians belanja daerah $\sim$ sebuah pengantar. Diakses dari https://syukriy.wordpress.com/2012/10/16/varians-anggaran-pendapatan-daerah/.

2013a. Belanja modal dan perubahan APBD. Diakses dari https://syukriy.wordpress.com/2013/11/01/belanjamodal-dan-perubahan-apbd/.

2013b. Defisit/surplus dan SILPA dalam anggaran daerah apakah saling berhubungan? Diakses dari https://syukriy.wordpress.com/2013/01/01/defisit-dan-surplus-dalam-anggaran-daerah-apakah-salingberhubungan/.

. 2013c. Pengaruh SiLPA terhadap belanja. Diakses dari https://syukriy.wordpress.com/2013/12/16/pengaruh-silpaterhadap-belanja/.

Abdullah, S., dan A. Junita. 2016. Bukti empiris tentang pengaruh budget ratcheting terhadap hubungan antara pendapatan sendiri dan belanja daerah pada kabupaten/kota di Aceh. Modus 28 (2). Diakses dari https://ojs.uajy.ac.id/index.php/modus/article/view/850/785.

Abdullah, S., dan J. A. Asmara. 2007. Perilaku oportunistik legislatif dalam penganggaran daerah: bukti empiris atas aplikasi agency theory di sektor publik. Jurnal Riset Akuntansi Indonesia 10 (1).

Abdullah, S., dan R. Nazry. 2015. Analisis varian anggaran pemerintah daerah penjelasan empiris dari perspektif keagenan. Jurnal Samudra Ekonomi dan Bisnis 6 (2): 272-83.

Abdullah, S., dan R. Rona. 2014. Pengaruh sisa anggaran, pendapatansendiri dan dana perimbangan terhadap belanja modal. IQTISHADIA (Journal of Islamic Economics and Business) 7 (1): 179-202. https://doi.org/10.21043/IQTISHADIA.V7I1.1106.

Alasa, M. A. 2016. Pengaruh sisa anggaran, besaran anggaran SKPD dan perubahan anggaran tahun sebelumnya terhadap perubahan anggaran belanja pada satuan kerja perangkat daerah kabupaten Gayo Lues. Universitas Syiah Kuala (tidak dipublikasikan). http://etd.unsyiah.ac.id/index.php?p=show_detail\&id=27041.

Andalia, D., Darwanis, dan S. Abdullah. 2012. Pengaruh varian pendapatan dan varian belanja terhadap sisa anggaran pemerintah daerah di kabupaten/kota se Aceh." Jurnal Akuntansi Pascasarjana Universitas Syiah Kuala 2 (1): 41-52.

Anessi-Pessina, E., M. Sicilia, dan I. Steccolini. 2012. Budgeting and rebudgeting in local governments: siamese twins? Public Administration Review 72 (6): 875-84. https://doi.org/10.1111/j.1540-6210.2012.02590.x.

Ayoola, T. 2013. The effect of cashless policy of government on corruption in Nigeria." International Review of Management and Business Research 2 (3). https://papers.ssrn.com/sol3/papers.cfm?abstract_id=2377908.

Baber, W. R., A. K. Gore, K. T. Rich, dan J. X. Zhang. 2013. Accounting restatements, governance and municipal debt financing. Journal of Accounting and Economics 56 (2-3): 212-27. https://doi.org/10.1016/J.JACCECO.2013.08.003.

Cai, H., H. Fang, dan L. C. Xu. 2010. Eat, drink, firms, government: an investigation of corruption from entertainment and travel costs of Chinese firms. Journal of Law and Economics, Forthcoming, July. https://ssrn.com/abstract=1641224.

Cavico, F. J., dan B. G. Mujtaba. 2010. Baksheesh or bribe : payments to government officials and the foreign corrupt practices act. Journal of Business Studies Quarterly 2 (1): 83-105.

Chen, Y., Z. Murgulov, S. G. Rhee, dan M. Veeraraghavan. 2016. Religious beliefs and local government financing, 
investment, and cash holding decisions. Journal of Empirical Finance 38 (September): 258-271. https://doi.org/10.1016/J.JEMPFIN.2016.07.009.

Douglas, J. W., dan A. L. Franklin. 2006. Putting the brakes on the rush to spend down end-of-year balances: carryover money in Oklahoma state agencies. Public Budgeting \& Finance 26 (3): 46-64. https://doi.org/10.1111/j.1540-5850.2006.00854.x.

Fisman, R., dan R. G. Hubbard. 2003. The role of nonprofit endowments. Edited by Edward L Glaeser. Chicago: University of Chicago Press. http://www.nber.org/chapters/c9971.

Forrester, J. P. 1991. Budgetary constraints and municipal revenue forecasting. Policy Sciences 24 (4): 333-356. https://doi.org/10.1007/BF00135880.

Forrester, J. P., dan D. R. Mullins. 1992. Rebudgeting: the serial nature of municipal budgetary processes. Public Administration Review 52 (5): 467. https://doi.org/10.2307/976806.

Gilligan, T. W., dan J. G. Matsusaka. 2001. Fiscal policy, legislature size, and political parties: evidence from state and local governments in the first half of the 20th century. National Tax Journal 54 (1): 57-82.

Gore, A. K. 2009. Why do cities hoard cash? determinants and implications of municipal cash holdings. The Accounting Review 84 (1): 183-207. https://doi.org/10.2308/accr.2009.84.1.183.

Halim, A., dan S. Abdullah. 2006. Hubungan dan masalah keagenan di pemerintah daerah. Jurnal Akuntansi Pemerintahan 2 (1): 53-64. https://doi.org/10.1017/CBO9781107415324.004.

Hansmann, H. B. 1980. The role of nonprofit enterprise. The Yale Law Journal 89 (5): 835. https://doi.org/10.2307/796089.

Ilna, N. 2015. Faktor-faktor yang mempengaruhi audit delay pada pemerintah daerah se-Indonesia. Universitas Lampung (tidak dipublikasikan). http://digilib.unila.ac.id/14012/.

Jones, L. R., dan K. J. Euske. 1991. Strategic misrepresentation in budgeting. Journal of Public Administration Research and Theory 1 (4): 437-60. https://doi.org/10.1093/oxfordjournals.jpart.a037102.

Kusyanti, Y., Nadirsyah, dan A. Syukriy. 2014. Analisis faktor-faktor yang berpengaruh terhadap perubahan anggaran belanja satuan kerja perangkat daerah: studi pada pemerintah kabupaten Aceh Besar tahun 2010-2014. Jurnal Akuntansi Pascasarjana Universitas Syiah Kuala 3 (2).

Larkey, P. D., dan R. A. Smith. 1989. Bias in the formulation of local government budget problems. Policy Sciences 22 (2): 123-66. https://doi.org/10.1007/BF00141382.

Lim, D. 2011. Budget ratcheting and agency problem. Dallas: University of Texas.

Mardiasmo. 2009. Akuntansi sektor publik. Yogyakarta: Andi.

Marlowe, J. 2011. Beyond 5 percent: optimal municipal slack resources and credit ratings. Public Budgeting \& Finance 31 (4): 93-108. https://doi.org/10.1111/j.1540-5850.2011.00994.x.

Martunis., Darwanis, dan S. Abdullah. 2014. Pengaruh sisa lebih perhitungan anggaran dan pendapatan asli daerah terhadap belanja daerah: analisis perubahan APBD kabupaten/kota se-Aceh. Jurnal Telaah dan Riset Akuntansi 7 (1): 52-57.

Marzalita, N., dan S. Abdullah. 2014. Faktor-faktor yang mempengaruhi perubahan anggaran belanja barang dan jasa pada pemerintah daerah di Indonesia. Jurnal Administrasi Akuntansi: Program Pascasarjana Universitas Syiah Kuala 3 (3): 46-58.

Mayer, H. J., dan M. R. Greenberg. 2001. Coming back from economic despair: case studies of small and medium size American cities. Economic Development Quarterly 15 (3): 203-16. https://doi.org/10.1177/089124240101500301.

Mayper, A. G., M. Granof, dan G. Giroux. 1991. An analysis of municipal budget variances. Accounting, Auditing \& Accountability Journal 4 (1). https://doi.org/10.1108/09513579110003358

McGuire, T. G. 1981. Budget-maximizing governmental agencies: an empirical test. Public Choice 36 (2): 313-22. https://doi.org/10.1007/BF00123787.

Modlin, S., dan L. S. M. Stewart. 2012. Cash management practices among southeastern county governments : 
proper utilization or excessive caution. Public Finance and Management 12 (2): 100-119.

Nelson, K. L., dan K. Nollenberger. 2011. Conflict and cooperation in municipalities. Urban Affairs Review 47 (5): 696-720. https://doi.org/10.1177/1078087411409129.

Nikmawati., S. Abdullah, dan H. Fahlevi. 2016. Analisis korelasi belanja daerah dalam perubahan APBK kabupaten/kota (studi di Aceh). Jurnal Magister Akuntansi Pascasarjana Universitas Syiah Kuala 5 (3): 39_ 49.

Opler, T., L. Pinkowitz, R. Stulz, dan R. Williamson. 1999. The determinants and implications of corporate cash holdings. Journal of Financial Economics 52 (1): 3-46. https://doi.org/10.1016/S0304-405X(99)00003-3.

Ramirez, A. 2011. Nonprofit cash holdings. Public Finance Review 39 (5): 653-681. https://doi.org/10.1177/1091142110381638.

Ruhmaini., S. Abdullah, dan Darwanis. 2018. Analisis serapan anggaran belanja pemerintah kabupaten Aceh Tengah. Jurnal Perspektif Ekonomi Darussalam 4 (1): 31-43. https://doi.org/10.24815/jped.v4i1.10912.

Smith, R. W., dan M. Bertozzi. 1998. Principals and agents: an explanatory model for public budgeting. Journal of Public Budgeting, Accounting \& Financial Management 10 (3): 325-53. https://doi.org/10.1108/JPBAFM10-03-1998-B001.

Triana, Y. 2016. Pengaruh sisa anggaran tahun lalu, perubahan anggaran tahun sebelumnya dan besaran anggaran (budget size) terhadap perubahan anggaran belanja Skpa pada pemerintah Aceh. Universitas Syiah Kuala (tidak dipublikasikan). http://etd.unsyiah.ac.id/index.php?p=show_detail\&id=25469. 